OPEN ACCESS

Edited by:

Dobrinka Genevska-Hanke,

University of Oldenburg, Germany

Reviewed by:

Lena Dal Pozzo,

Università degli Studi di Firenze, Italy

lanthi Tsimpli,

University of Cambridge,

United Kingdom

*Correspondence:

Elisa Di Domenico

elisa.didomenico@unistrapg.it

Specialty section:

This article was submitted to

Language Sciences,

a section of the journal

Frontiers in Psychology

Received: 27 March 2018

Accepted: 18 December 2018

Published: 10 January 2019

Citation:

Di Domenico E and Baroncini

(2019) Age of Onset and Dominance

in the Choice of Subject Anaphoric

Devices: Comparing Natives

and Near-Natives of Two Null-Subject

Languages. Front. Psychol. 9:2729.

doi: 10.3389/fpsyg.2018.02729

\section{Age of Onset and Dominance in the Choice of Subject Anaphoric Devices: Comparing Natives and Near-Natives of Two Null-Subject Languages}

\author{
Elisa Di Domenico ${ }^{1 *}$ and Ioli Baroncini ${ }^{1,2}$ \\ ${ }^{1}$ Dipartimento di Scienze Umane e Sociali, Università per Stranieri di Perugia, Perugia, Italy, ${ }^{2}$ Scuola Superiore di Dottorato e \\ di Specializzazione, Università per Stranieri di Siena, Siena, Italy
}

Several studies have highlighted the role of cross-linguistic influence in determining the over-use of overt subject pronouns in near-native speakers of a null-subject language as Italian. In this work we inquire on the role of factors different from cross-linguistic influence in the choice of anaphoric devices in near-natives, such as age of onset of exposure and dominance. In order to do so, comparing the productions of two groups of natives speakers, we first single out two null-subject languages, Italian and Greek, which do not differ significantly as far as subject anaphoric devices are concerned and thus instantiate a suitable language combination to investigate the role of factors other than cross-linguistic influence in bilingual speakers of these two languages (Study 1). In Study 2, we compare the productions of a group of native speakers and two groups of near-native speakers in Italian: Greek-Italian bilinguals from birth and L2ers of Italian with Greek as an L1. Results reveal that over-use of overt pronouns in near-natives occurs in the absence of cross-linguistic influence and that age of onset of exposure is a relevant factor: while bilinguals from birth do not differ from native speakers, L2ers over-use overt pronouns compared to both native speakers and bilinguals from birth. In order to establish whether dominance is a possible factor determining bilinguals' choice of subject anaphoric devices, in Study 3, we compare two groups of GreekItalian bilinguals from birth: bilinguals living in Greece (whose predominant language is Greek) and bilinguals living in Italy (whose predominant language is Italian). Results reveal no effect of dominance in the production of overt subject pronouns. We found, however, an unexpected effect in the predominant language of one group: bilinguals living in Greece produce significantly more null pronouns and less lexical DPs in Greek compared to bilinguals living in Italy. We interpret this effect as stemming from the need to differentiate the two languages that these bilingual speakers have to handle in everyday life. Interestingly, this effect is found in the predominant language rather than in the non-predominant one.

Keywords: age of onset, dominance, Italian, Greek, overt subject pronouns, null subject pronouns (pro), natives, near-natives 


\section{INTRODUCTION}

Some languages of the world are null-subject languages. In these languages the subject of finite clauses (whether matrix or embedded) can be left unpronounced, as in (1.b/d), (2.b/d) and (3.b/d):

(1) a. Gianni ha parlato G. spoke

b. pro Ha parlato He spoke

c. Lui ha parlato He spoke

d. Gianni ha detto che pro ha parlato G. said that he spoke

Italian

(2) a. Juan habló

b. pro habló

c. Él habló

d. Juan dijo que pro habló

(3) a. O Janis milise/ Milise o Janis

b. pro Milise

c. Aftos milise

d. O Janis ipe oti pro milise

Greek $^{1}$

Though phonetically unrealized, the null subject is syntactically active, and is standardly indicated as pro, as shown in the.$b$ and.$d$ examples above. ${ }^{2}$ Given that null-subject languages have both overt (as shown in the c. examples above) and null subject pronouns, an interesting question is what the division of labor is between the two series of pronouns.

Calabrese (1986) for instance has noted that in Italian, in cases like (4), the null pronoun takes the antecedent in subject position, while the overt pronoun preferentially takes an antecedent which is not the subject:

(4) a. Quando Carlo i $_{\mathrm{i}}$ ha picchiato Antonio pro $_{\mathrm{i} / *_{\mathrm{j}}}$ era ubriaco

b. Quando Carlo ${ }_{i}$ ha picchiato Antonio ${ }_{j}$ lui $_{j} / *_{i}$ era ubriaco When C. hit A pro/he was drunk

${ }^{1}$ Greek third person personal pronouns disappeared around the 5th-6th century B.C. (Panagiotidis, 2000) and were substituted by demonstratives, as aftos in (3.c; this one) or ekinos (that one), with an anaphoric function. These demonstrative pronouns can also have an inanimate antecedent, contrary to Italian overt pronouns. In Italian, demonstrative pronouns can also be used with anaphoric function, with inanimate referents only or, with a pejorative flavor, in sub-standard varieties with animate/human referents. (3.a) shows another difference between Greek and Italian, in that Greek freely allows post-verbal subjects (Roussou and Tsimpli, 2006), and VSO, while in Italian the post-verbal position of subjects is restricted to new-information focus subjects and VSO is impossible (Belletti, 2001, 2004). Post-verbal subjects and VSO are also possible in Spanish, although Greek and Spanish partly differ, word order being more flexible in Greek than in Spanish, since VSO is allowed by different mechanisms in the two languages (Roussou and Tsimpli, 2006).

${ }^{2}$ The null pronoun, for instance, binds the anaphor se stesso in (i.c) as the lexical DP Gianni does in (i.a). Contrary to pronouns (lo in i.b), anaphors must be bound within the clause containing them:

(i) a. Paolo $o_{i}$ ha detto [che [Gianni $i_{j}$ proteggerà se stesso $\left.\left.o_{j}\right]\right]$

P. $\quad$ said that $\mathrm{G}$. will protect himself

b. Paolo ha detto [che [Giannij lo $*_{j}$ proteggerà]]

P. $\quad$ said that $\mathrm{G}$. him will protect

c. Paolo ha detto [che [pro $o_{\mathrm{i}}$ proteggerà se stesso $\left.\mathrm{i}_{\mathrm{i}}\right]$

P. said that he will protect himself
Noting that a post-verbal subject cannot be the antecedent of a pronoun (whether null or overt, as shown in (5)) and that pro can co-refer with the dative PP of so called Psych-verbs in preverbal position (6), the author proposes that the property 'subject' is not sufficient to characterize the referential properties of pro:

(5) a. *Ha parlato Carló́ quando prò è arrivato

b. * Ha parlato Carló quando lui $\mathrm{i}_{\mathrm{i}}$ è arrivato. Spoke C. when pro/he arrived

(6) Poiché a Giovanni $i_{i}$ piace Maria, pro $o_{\mathrm{i}}$ fa di tutto per farsi bello ai suoi occhi

Because G. likes M. he does everything to show off for her

Calabrese (1986) proposes that the relevant property is instead 'Subject of primary predication' (or Thema). ${ }^{3}$

As far as overt pronouns ('stressed' in his terms) are concerned, Calabrese (1986) assumes that they are only used when the occurrence of their referent is not expected, proposing a principle like (7):

(7) Assign the feature [+ stressed] to a pronominal $\mathrm{X}$ only when the occurrence of the referent of $\mathrm{X}$ is not expected [Calabrese, 1986: 7, ex. (18)]

Assuming that expectedness (i.e., high probability of occurrence) is correlated to low content of information, while unexpectedness (i.e., low probability of occurrence) is correlated to high content of information, he argues that (7) simply prevents giving more information than is required, and hence is a direct consequence of the second maxim of quantity of Grice (1975). ${ }^{4}$

We may thus easily derive from (7) the fact that overt pronouns, at least in Italian and Greek, are required only in case of topic shift or focalization, i.e., when their referent is unexpected. But when the referent is expected, overt pronouns are impossible:

(8) a. Poiché pro $_{\mathrm{i}}$ ha visto quel film, Mario ì si è spaventato

b. ${ }^{*}$ Poiché lui $i_{\mathrm{i}}$ ha visto quel film, Mario i si è spaventato Because pro/he saw that film, M. was frightened [Calabrese, 1986 ex. (19) and (23)]

(9) a. Epidi pro $_{\mathrm{i}}$ ide ekini tin tenia, o Marios tromaxe. $_{\mathrm{i}}$

b. ${ }^{*}$ Epidi aftos ${ }_{i}$ ide ekini tin tenia, o Marios tromaxe. $^{6}$

Things appear to work in part differently for near-native speakers, as brought to light by a number of studies. While a natural reply to (10.A) would be (10.B1) for a native speaker, near-natives may also produce (10.B2):

\footnotetext{
${ }^{3}$ Experimental findings by Carminati (2002) suggest indeed that pro, at least in intra-sentential anaphora, looks for an antecedent in Spec, IP. Subjects of predication share properties with topics: according to Rizzi (2005, 2018), subjects and topics share an 'aboutness' property. According to Lambrecht (1994: 118) topics are 'the thing which the proposition expressed by the sentence is about.'

${ }^{4}$ Do not make your contribution more informative than is required' [Grice, 1975: 45]. Calabrese (1986: fn. 6) suggests that the Avoid Pronoun Principle (Chomsky, 1981: 65) must be interpreted in a similar vein.

${ }^{5}$ A similar claim is made by Chiou (2013) for Greek.

${ }^{6}$ Note that (8.b) and (9.b) are possible with a different indexing, i.e., if lui/aftos does not co-refer with Mario.
} 
(10) A. Perché Giorgio si è licenziato? Why did G. resign

B1. Perché pro non sopportava più il direttore

B2. Perché lui non sopportava più il direttore Because pro/he could not stand the boss anymore [Adapted from Sorace, 2006: 507]

Tsimpli et al. (2004) for instance studied the production and comprehension of overt and null subject pronouns by native speakers of Italian and native speakers of Greek who were nearnative speakers of English as an L2 and had a minimum of 6 years of residence in Britain. They were hence experiencing attrition from the L2. ${ }^{7}$ As for the Italian experimental subjects, the authors found a significant difference between the control and the experimental group in the choice of the matrix subject as a possible referent of the overt pronoun in the embedded sentence. ${ }^{8}$

Sorace and Filiaci (2006) studied the comprehension of null and overt subject pronouns in Italian by English speakers who had learned Italian as adults, reaching a near-native level of proficiency. Compared to native speakers, near-natives had a significantly higher preference for the subject of the matrix clause as a possible antecedent of overt subject pronouns. ${ }^{9}$

Belletti et al. (2007) were also concerned with near-native speakers of Italian whose native language was English, and who had started learning Italian as adults. Their findings on pronoun comprehension and production matched: overt pronouns were over-produced and also interpreted in co-reference with a topical antecedent by these near-native speakers.

Serratrice et al. (2004) studied the productions of an ItalianEnglish bilingual child, finding an overuse of overt pronouns in her Italian. ${ }^{10}$

Taken together these studies support the idea that the overuse and over-interpretation of overt pronouns is due to crosslinguistic influence from English, a language which has only overt pronouns. But then the question is why the influence goes only from English to Italian and not in the other direction. One possibility is that these speakers chose the option compatible with

\footnotetext{
${ }^{7}$ The study was also concerned with post-verbal subjects, which are possible in null-subject languages but not in non-null subject languages, as originally noted by Rizzi (1982). As noted in footnote 1, Greek and Italian, however, differ in this respect.

${ }^{8}$ Results concerning the interpretation of null and overt pronouns are presented in Tsimpli et al. (2004) only for the Italian participants. Experimental sentences were of the kind given in (i.a) and (i.b):
}

(i) a. L’anziana signora saluta la ragazza quando lei attraversa la strada The old woman greets the girl when she is crossing the street

b. Quando lei attraversa la strada, l'anziana signora saluta la ragazza When she is crossing the street, the old woman greets the girl

Results were particularly clear in the (i.a) condition. These results concerning the comprehension of overt pronouns are however not matched in the production tasks, such as the Story Telling task, for which, as the authors acknowledge, no significant results were attested for either group (Tsimpli et al., 2004: 267).

${ }^{9}$ Experimental materials were very similar to those employed by Tsimpli et al. (2004). Here as well, results were particularly clear in cases like (i.a) of footnote 8.

${ }^{10}$ Several studies tackle indeed this issue examining spontaneous productions of bilingual children with a null and a non-null subject language. See, among others, Paradis and Navarro (2003) on a Spanish-English child, Pinto (2006) on two Dutch-Italian children), Hacohen and Schaeffer (2007) on a Hebrew-English child. They all found an over-use of overt subjects in the null-subject language. both their languages: coherently with Hulk and Müller's (2000) hypothesis, cross-linguistic influence does not occur in young bilinguals unless input from one of the languages can be analyzed through the grammar of the other language. Another possibility is, however, that overt pronouns are, for some reason, 'simpler' for speakers of more than one language: if so, they should be over-produced (and over-interpreted) also in the absence of cross-linguistic influence.

Sorace and Filiaci (2006: 345) quote production data collected by Bini (1993) from low-intermediate Spanish learners of Italian who use overt pronouns in contexts in which both Italian and Spanish would require a null pronoun: since cross-linguistic influence cannot be implicated in this case, the authors suggest that overt pronouns may be a default form.

Sorace et al. (2009) compare the preferences toward null and overt subject pronouns in Italian, in a [+Topic Shift] and [-Topic Shift] condition by different groups of subjects: Italian monolingual adults, Italian monolingual children, English-Italian bilingual children (6-7 and 8-10 years old, living in Italy and living in the United Kingdom), Spanish-Italian bilingual children.

In the [-TS] condition younger children chose significantly more overt pronouns than older children and adults, and older children more than adults. Children with English as the community language were more likely to choose inappropriate overt pronouns than children with Italian as the community language at the age of 6-7, but not at 8-10. Italian monolingual children aged 6-7 chose significantly more overt pronouns than adults. Spanish-Italian bilinguals were significantly more likely to opt for an overt pronoun than the monolinguals, but they were not significantly different from the English-Italian bilinguals. In the [+TS] condition bilingual children (regardless of the language combination) accepted more null subject pronouns than monolingual children. ${ }^{11}$

These results are very important in that they show that establishing the appropriate conditions for pronoun resolution is a phenomenon which is acquired late, in part independently from cross-linguistic influence in bilingual children, since SpanishItalian bilingual children behaved differently from Italian monolingual children. These results also show that the pattern is not completely asymmetric, given some variability in the acceptance of null pronouns in [+TS] contexts.

The fact that the preferences of Spanish-Italian bilingual children may not be due to cross-linguistic influence has been challenged, however, by a self-paced reading study on Spanish and Italian (Filiaci et al., 2013) that found that pronominal preferences may not be the same in Italian and Spanish, although they are both null-subject languages. Sentences containing an overt pronoun congruent with a complement antecedent (as in (11)) were read significantly faster in Italian, but not in Spanish, suggesting that overt pronouns in Spanish are also compatible with a topic antecedent:

\footnotetext{
${ }^{11}$ The authors propose difficulties at integrating different types of information in real time as an explanation for their results. Along the same line, Sorace (2011) suggests that there could also be a difference in the processing resources available for bilingual and monolingual speakers.
} 
(11) a. Dopo che Giovanni $i_{i}$ ha criticato Bruno $j$ così ingiustamente, lui $i_{j}$ si è sentito offeso

b. Despues de que Bernardo ${ }_{i}$ criticó a Carlos $_{j}$ tan injustamente, él $l_{j}$ se sintió muy ofendido.

After that G./B.i has criticized B./C.j so unjustly, he felt offended

This makes the authors explicitly claim that the findings in Sorace et al. (2009) concerning the preference differences of Spanish-Italian bilingual children compared to Italian monolingual children could indeed be due to cross-linguistic influence from Spanish (Filiaci et al., 2013: 17).

This suggests that in order to verify whether the overuse/ over-acceptance of overt subject pronouns in bilinguals is not only due to cross-linguistic influence, care must be put in the choice of the language combination of bilingual speakers, since not all null-subject languages are alike in this respect.

In this work we present three studies concerning adult narrative productions in Italian and Greek by two groups of native speakers (Italian natives and Greek natives), two groups of adult Italian-Greek bilinguals from birth (Bilinguals living in Greece and Bilinguals living in Italy) and a group of adult native speakers of Greek who started to learn Italian in adulthood reaching a near-nativeness level of proficiency (L2ers).

In Study 1, we compare the productions of the two groups of native speakers, highlighting that there are no significant quantitative differences in Greek and Italian as far as the implementation of null pronouns, overt pronouns and lexical DPs are concerned, so that Italian and Greek appear as a suitable language combination to study the factors influencing bilinguals' choices of anaphoric devices, in the absence of effects related to cross-linguistic.

In Study 2, we compare the productions in Italian of a group of native speakers and two groups of near-native speakers: bilinguals from birth and L2ers. Results reveal that near-natives over-use overt pronouns also when cross-linguistic influence is absent and that age of onset of exposure to Italian is a relevant factor in this respect: while bilinguals from birth do not differ from native speakers, L2ers over-use overt pronouns compared to both native speakers and bilinguals from birth.

In order to establish whether dominance is a possible factor determining speakers' choice of anaphoric devices, in Study 3, we compare two groups of bilinguals: bilinguals living in Greece and bilinguals living in Italy. Results reveal no effect of dominance with respect to the production of overtpronouns, neither in Italian nor in Greek. We found, however, an unexpected effect in the predominant language of one of the groups: bilinguals living in Greece produce significantly more null pronouns and less lexical DPs in Greek compared to bilinguals living in Italy. We interpret this effect as stemming from the need to differentiate the two languages that this bilingual group has to handle in everyday life. Interestingly, this effect is found in the predominant language rather than in the non-predominant one, and does not concern overt pronouns.

\section{STUDY 1: SUBJECT ANAPHORIC DEVICES IN ITALIAN NATIVES AND GREEK NATIVES}

The study conducted by Filiaci et al. (2013) reviewed in the previous section suggests that an analogous null/overt pronouns division of labor among null-subject languages should not be taken for granted. Spanish, as the authors show, differs from Italian in that overt pronouns appear to retrieve a subject antecedent to a greater extent in Spanish compared to Italian. In Study 1, we therefore compare the productions of two groups of native speakers (Italian native speakers and Greek native speakers) in order to see whether the proportion of null and overt pronouns and lexical DPs produced is comparable in the two groups. If this analysis reveals no significant differences, differences in the productions of speakers of the two languages could not be attributed to cross-linguistic influence.

\section{Subjects}

20 subjects participated in Study 1: 10 native speakers of Italian and 10 native speakers of Greek.

Italian Natives (6 male; 4 female) had a mean age of 32 (range 19-58). They were born in Italy and had been living there by the end of testing. Three of them had a university degree, while seven had a high school degree and were attending university.

Greek Natives ( 4 male; 6 female) had a mean age of 29 (range 19-58). They were born in Greece and had been living there by the end of testing. Four of them had a university degree, while six had a high school degree and were attending university.

\section{Materials and Methods Ethical Considerations}

There is no ethical committee in our institutions, and for this reason this study could not undergo an ethical reviewing process, not required according to the guidelines of our institution and national regulations in such cases. The subjects in this study were adults who participated in it on a voluntary basis and came to the place of data collection for this purpose only. They were informed about the general aims of the research and gave their written informed consent to the treatment of the data they produced, including the publication of the results. In order to protect their anonymity, subjects were coded only by progressive numbers in the data analysis.

\section{Procedure}

Subjects were asked to watch a short movie (The Pear Film) and then tell the story. ${ }^{12}$ Subjects productions were recorded and then transcribed with the help of the CLAN system (part of the CHILDES tools, MacWhinney, 2000). Subjects were tested individually in a quiet room and the interviewer did not interact with them during their narration.

\footnotetext{
${ }^{12}$ The Pear Film is a 6-min film without dialogs. It was created at the University of California at Berkeley in 1975 by a group of linguists to collect narration data. See Chafe (1980) for a first report of this research. Years later, data collected through the Pear Film have become part of the experimental material in works dedicated to the study of pronoun production and resolution in bilingual contexts, such as Tsimpli et al. (2004) and Belletti et al. (2007).
} 


\section{Defining the Reference Total}

The narrations collected with the procedure described above were then analyzed in order to study the occurrences of null and overt subject pronouns as well as of subject lexical DPs chosen by the speakers. Given the nature of the task (semispontaneous production), the two corpora contained a great variety of clausal types. Not all of them, however, can be considered suitable environments to study speakers' choice of subject referring expression, since in many of these clausal types no true clause-internal choice is possible as far as their subject is concerned, since it is syntactically determined. For instance, this is the case in subject relatives, where, according to a raising analysis of this clausal type, the subject is the copy of the moved head of the relative, or in pseudo-relatives, where the antecedent must be overt and the internal subject is invariably null. In subject clefts the subject is focalized, hence it cannot be null. As for absolute gerundive and participial, adjectival and prepositional small clauses, their subject is standardly assumed to be PRO. The subject is also syntactically determined in Italian infinitives (whether control, raising or ACC-ing) and in Greek $n a$ and ke clauses, when they are complement of certain verbs. ${ }^{13}$ Finally, the subject of existential sentences is syntactically determined, in Italian as well as in Greek. ${ }^{14}$

For this reason, we kept in what we call the 'Reference Total' only those clausal types whose subject can be chosen clause-internally by the speaker, i.e., finite and copular sentences as well as non-subject relatives and non-subject clefts.

Since we adopted this 'free clause-internal choice' criterion, other cases had to be excluded, as well.

Finite sentences whose subject was the narrator or included narrator+ interviewer were also excluded, since they were in the first person (singular or plural), and a choice between a null pronoun, an overt pronoun or a lexical DP is only possible in the third person, lexical DPs being excluded from first and second person. ${ }^{15}$

\footnotetext{
${ }^{13}$ Greek doesn't have infinitives, but rather embedded sentences introduced by $n a$ or ke complementizers whose verbs are inflected. Verbs in the matrix clause that embed a na or ke complement clause are perception, knowledge aspectual and modal verbs (for a complete list see e.g., Ingria, 2005; Spyropoulos, 2007). For these cases, there is disagreement in the relevant literature as to the kind of subjects inside these clausal types (see e.g., Philippaki-Warburton and Catsimali, 1999; Alexiadou and Anagnostopoulou, 2002; Spyropoulos, 2007 among others, and the references quoted there) but all analyses agree on the fact that inside these complement clauses the subject (as well as tense) is dependent on the subject of the matrix clause and can never be overt. $n a$ clauses can also occur as independent clauses and in this case they are considered subjunctive clauses (hence with an independent subject, which can be null or overt). Matrix clauses with verbs like elpizo (hope), perimeno (wait/expect), pistevo (believe) embed na clauses whose subject (and tense) is independent from the one of the matrix clause (Spyropoulos, 2007).

${ }^{14}$ Greek has two kinds of existential sentences, those involving the verb ine (be$3 \mathrm{sg} / \mathrm{pl}$ ) and those involving the verb echi (have-3sg), whose subject can never be overt. Italian existential sentences contain the locative clitic $c i$ and the verb essere (be), and a so called 'pivot' which can be definite or indefinite. In the type of existential most attested in our corpus, the one containing an indefinite pivot, the (expletive) subject is assumed to be $c i$.

${ }^{15}$ Some of the sentences with a 'narrator' subject were indeed stock phrases such as Gr. xero go (I don't know, lit. know I) or It. diciamo (let's say).
}

Some of the sentences were used to introduce (rather than to resume) a Discourse Referent, and since first mention is always lexical, we excluded those sentences as well.

In this way we obtained the Reference Total, which consists of 387 sentences produced by the Italian natives and 454 sentences produced by the Greek natives. In this Reference Total we analyzed the occurrences of null pronouns, overt pronouns and lexical DPs.

\section{Results $^{16}$}

Null subject pronouns are the most employed anaphoric device (67.18\% by Italian natives; $69.38 \%$ by Greek natives), followed by lexical DPs (24.28\% by Italian natives; $23.12 \%$ by Greek natives), while overt pronouns are quite rare $(6.20 \%$ in the Italian natives Reference Total; $3.37 \%$ in the Greek natives Reference Total). We have singled out another resumption device which we call 'other' and which consists of various quantificational expressions such as It. 'uno' (one), 'uno dei tre' (lit. one out of the three), 'tutti' (all of them), Gr. 'enas apo aftous' (one of them). Instanced of 'other' are quite rare, as well (2.06 \% in the Reference Total of the Italian natives; $3.74 \%$ in the Reference Total of the Greek natives).

A $\chi^{2}$-test reveals no significant difference between the two groups neither for pro $\left(\chi^{2}=0.4675\right.$, n.s. $)$ nor for lexical DPs $\left(\chi^{2}=0.1561\right.$, n.s. $)$, overt pronouns $\left(\chi^{2}=2.2157\right.$ with Yates correction, n.s.), 'other' ( $\chi^{2}=1.4977$ with Yates correction, n.s.). The same goes for the case of collapsing overt pronouns and 'other' ( $\chi^{2}=0.0844$ with Yates correction, n.s.). Figure 1 reports the comparisons. ${ }^{17}$

\section{Discussion}

Results show a very similar pattern characterizing Italian native speakers' and Greek native speakers' choice of referring expressions. In particular, they show that there are no significant differences in the amounts of the various referring expressions chosen by the speakers. Null pronouns are widely employed, followed by lexical DPs, while overt pronouns are quite rare in both groups. Results are important in that they show that Italian and Greek, despite their differences, are comparable languages, at least as far as production is concerned, with respect to the relative amount of anaphoric devices employed. ${ }^{18}$ This in turn means that in bilingual speakers of both these languages, no effect related to cross-linguistic influence is expected with respect to the issue at stake. With this in mind, we move to Study 2.

\footnotetext{
${ }^{16}$ Results are summarized in Supplementary Table 1 (Italian Natives) and Supplementary Table 2 (Greek Natives), where the Reference Total of the sentences for the two groups is shown, together with the indication of the clausal type and of the occurrences and percentages of the kind of referring expression employed.

${ }^{17}$ Given the small-scale nature of the data discussed in this study, we chose the $\chi^{2}$-test as a suitable non-parametric procedure to analyze our data. Group responses are indeed quite representative of individual ones, as revealed by $a \leq 0.5$ coefficient of variation in responses for pro, lexical DPs and overt pronouns in Greek natives and for pro and lexical DPs in Italian natives. The latter holds for all the experimental groups discussed in the present work.

${ }^{18}$ As noted in footnote 1, Greek allows post-verbal subjects more than Italian. Our data support this fact in that post-verbal subjects in the Reference Total of the Greek natives are much more widespread (50.35\%) than in the Reference Total of the Italian natives $(21.42 \%)$. The difference is highly significant $\left(\chi^{2}=22.6082\right.$ with Yates correction, significant at $p<0.05,0.01$, and 0.005 ).
} 


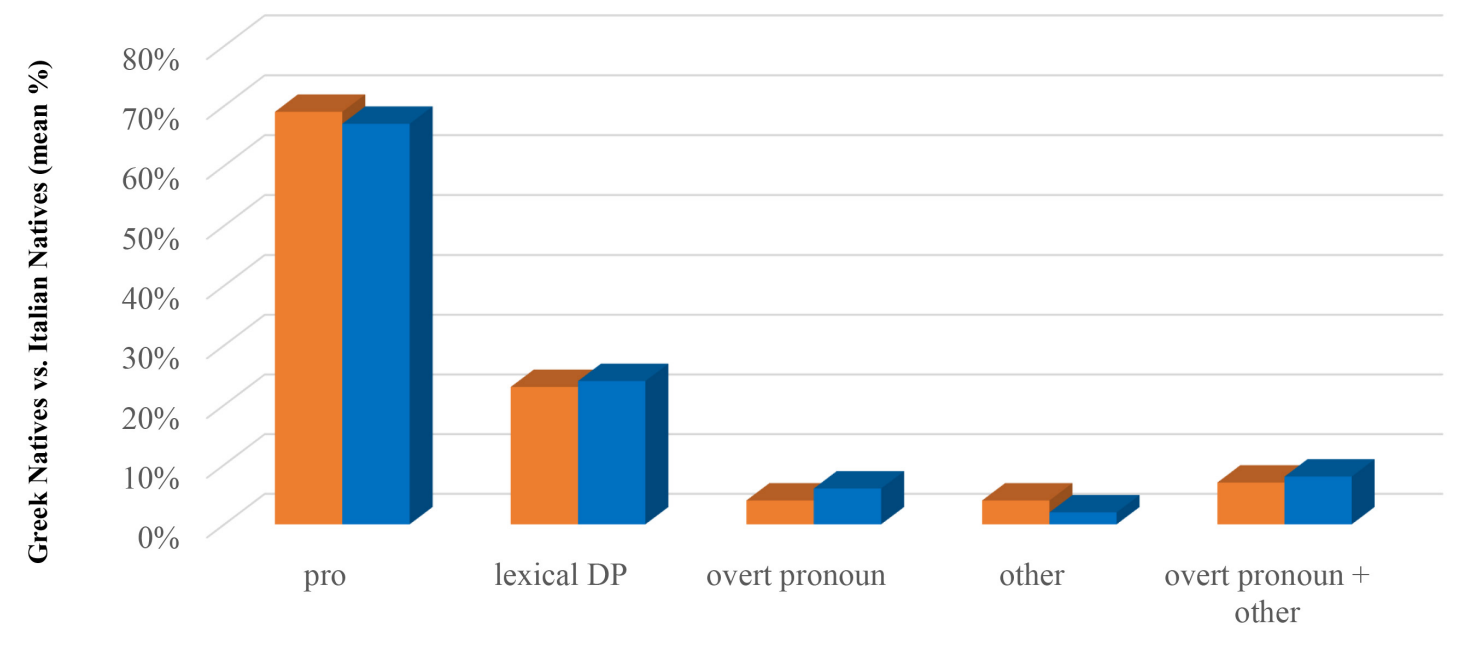

घreek Natives - Italian Natives

FIGURE 1 | Subject anaphoric devices in Greek Natives and Italian Natives.

\section{STUDY 2: SUBJECT ANAPHORIC DEVICES IN NATIVE AND NEAR-NATIVE SPEAKERS OF ITALIAN}

The results of Study 1 show that native speakers of Italian and native speakers of Greek do not differ significantly in the production of null and overt pronominal as well as lexical DP subjects. Thus, we do not expect any effects of cross-linguistic influence with respect to the anaphoric devices chosen by the speakers of both these languages. These data will be relevant to establish whether the over-use of overt pronouns observed in near-natives by the studies described in the Introduction is due to cross-linguistic influence alone, or whether other factors are involved as well: if Greek-Italian bilingual speakers over-use overt pronouns, this cannot be due to cross-linguistic influence.

\section{Subjects}

30 subjects participated in Study 2: the group of 10 native speakers of Italian of Study 1 (henceforth Natives), a group of 10 Greek-Italian bilinguals from birth living in Greece (henceforth Bilinguals in Greece), and a group of 10 native speakers of Greek who started to learn Italian after puberty and had reached a near-native level of proficiency in this language (henceforth L2ers).

Natives have been described in the section 'Subjects' of Study 1. As for Bilinguals in Greece ( 3 male; 7 female) their mean age at the time of testing was 21 (range 16-33). They were living in Greece at the time of testing and had been living there most of their lives. They were tested in Greece. They were all bilinguals from birth, with one parent native speaker of Greek and one parent native speaker of Italian. Despite living in Greece, they all also used Italian on a regular basis. ${ }^{19}$ As for their education, 6 of

\footnotetext{
${ }^{19}$ See section "The Near-Nativeness Level of the Subjects" for more information concerning their level of proficiency in the two languages.
}

them were attending the last year of the Italian State School of Athens, 1 had just graduated from this school, 3 had a university degree, and had previously attended the Italian State School of Athens.

As for L2ers ( 4 male; 6 female), their mean age at the time of testing was 32 (range 21-52). They were born in Greece and had spent there at least the first 18 years of their lives. At the time of testing they were living in Italy, where they were tested. The length of their residence in Italy was 7 years on average Their age of onset of exposure to Italian ranged from 15 to 28 . As for their education 4 had a university degree and 6 had a high school degree and were attending university in Italy.

\section{Materials and Methods \\ Ethical Considerations}

The same ethical considerations holding for Study 1 (see section "Ethical Considerations") hold for this study as well. The data collection at the Italian State School of Athens (which concerns 6 subjects, see section "Subjects" above) was authorized by the school pro-Rector.

\section{Procedure}

As described for Study 1, subjects were asked to watch The Pear Film and then tell the story, first in Italian and then in Greek. The subjects productions were recorded and then transcribed with the help of the CLAN system. Subjects were tested individually in a quiet room and the interviewer did not interact with them during their narration.

\section{The Near-Nativeness Level of the Subjects}

In order to see whether the materials collected were appropriate for our study, we first performed a near-nativeness test on these materials, adapting White and Genesee's (1996) near-nativeness test along the lines of Contemori et al. (2015) and Dal Pozzo and Matteini (2015). Three native speakers of Italian evaluated 
the oral productions in Italian of the experimental subjects, indicating their judgments with respect to five distinct aspects (morphology, syntax, vocabulary, pronunciation, fluency) on a scale of $10 \mathrm{~cm} .{ }^{20}$ The mean value of these five judgements constitutes the near-nativeness value assigned by each judge to each participant. The final near-nativeness value of each participant corresponds to the mean value of the values expressed by each judge. A speaker is considered near-native if her/his mean value ranges from 8.5 to 9.5 .

Taken as a group, Bilinguals in Greece had a mean value of 8.98 (range 8.70-9.28). L2ers had a mean value of 8.88 (range 8.509.33). In order to have a line of comparison for our study, we had the same three judges evaluate the Natives productions as well: taken as a group, Natives had a mean value of 9.79 (range 9.649.96).

Although not entirely relevant for this study (but see section "Extension" below), we also asked three native speakers of Greek to evaluate the productions of the Bilinguals and the L2ers in Greek. ${ }^{21}$ Taken as a group, Bilinguals had a mean value of 9.34 (range 8.61-9.80) while L2ers had a mean value of 9.73 (9.569.92). Note that the same Greek judges evaluated the productions of the group of the Greek native speakers of Study 1. Taken as a group, they had a mean value of 9.87 (range 9.75-10). ${ }^{22}$

\section{Defining the Reference Total}

The Reference Total was derived with the same procedure described for Study 1. As mentioned, the Natives' Reference Total consists of 387 sentences. The Bilinguals in Greece Reference Total consists of 241 sentences, while the L2ers' Reference Total consists of 255 sentences.

\section{Results $^{23}$}

As in Study 1, pro is the preferred anaphoric device in all groups (67.18\% Natives, $63.90 \%$ Bilinguals, $60.68 \%$ L2ers), followed by lexical DPs (24.28\% Natives, 29.46\% Bilinguals, $23.52 \%$ L2ers), overt pronouns (6.20\% Natives, $5.80 \%$ Bilinguals, $14.50 \%$ L2ers) and 'other' (2.06\% Natives, $0.82 \%$ Bilinguals, $1.17 \%$ L2ers).

As for pro, Natives do not differ from Bilinguals $\left(\chi^{2}=0.7126\right.$, n.s.) nor from L2ers ( $\chi^{2}=2.7540$, n.s.); Bilinguals and L2ers do not differ from each-other $\left(\chi^{2}=0.5122\right.$, n.s. $)$.

Lexical DPs as well appear equally employed: Natives do not differ from Bilinguals $\left(\chi^{2}=2.0502\right.$, n.s. $)$ nor from L2ers $\left(\chi^{2}=0.0487\right.$, n.s. $)$, Bilinguals and L2ers do not differ from each-other $\left(\chi^{2}=2.2426\right.$, n.s.).

Similarly, as to the category 'other', Natives do not differ from Bilinguals $\left(\chi^{2}=0.7688\right.$ with Yates correction, n.s.) nor from

\footnotetext{
${ }^{20}$ Two of the Italian judges ( 2 male; 1 female, aged $25-29$, living in Italy) were teachers of Italian as an L2, and another was working for an organization for immigrants.

${ }^{21}$ The Greek judges (1 male; 2 female, aged $25-31$, living in Greece) were teachers of Greek as an L2.

${ }^{22}$ Supplementary Table 9 reports the mean value of (near-) nativeness for each group of experimental subjects participating in Study 1, Study 2 and Study 3.

${ }^{23}$ Supplementary Table 3 reports the Reference Total concerning Bilinguals in Greece, together with the indication of the clausal type and of the occurrences and percentages of the kind of referring expression employed. The same is shown in Supplementary Table 4 for the L2ers. As for Natives, as already presented, the same is shown in Supplementary Table 1
}

L2ers $\left(\chi^{2}=0.2918\right.$ with Yates correction, n.s.), Bilinguals and L2ers do not differ from each-other $\left(\chi^{2}=0.0040\right.$ with Yates correction, n.s.).

Things appear different as far as overt pronouns are concerned. Natives do not differ from Bilinguals $\left(\chi^{2}=0.0008\right.$ with Yates correction, n.s.) but they significantly differ from L2ers $\left(\chi^{2}=11.3923\right.$ with Yates correction, significant at $p<0.05 ; 0.01$; $0.005)$. L2ers also significantly differ from Bilinguals $\left(\chi^{2}=9.2462\right.$ with Yates correction, significant at $p<0.05 ; 0.01 ; 0.005)$.

These differences are replicated when overt pronouns and 'other' are collapsed: Natives do not differ from Bilinguals $\left(\chi^{2}=0.3518\right.$ with Yates correction, n.s.) but they significantly differ from L2ers $\left(\chi^{2}=7.7651\right.$ with Yates correction, significant at $p<0.05 ; 0.01)$; L2ers significantly differ from Bilinguals $\left(\chi^{2}=9.2427\right.$ with Yates correction, significant at $p<0.05 ; 0.01$; 0.005). Results are shown in Figure 2.

\section{Discussion}

Results clearly reveal that L2ers use significantly more overt pronouns than Natives and Bilinguals, while Bilinguals from birth behave like Natives in this respect. A significant difference between L2ers on one side and Natives and Bilinguals on the other is observed only with respect to overt pronouns (considered individually or collapsed with 'other').

Given that no effect related to cross-linguistic influence can be called into question in this respect for our experimental subjects (as revealed by Study 1), and that Bilinguals and L2ers have a comparable level of proficiency in Italian as attested, the relevant factor that Study 2 singles out is age of onset of exposure to Italian. $^{24}$

Study 2 thus reveals first of all that over-use of overt subject pronouns also occurs in the absence of cross-linguistic influence. Furthermore, Study 2 reveals that it occurs only in a specific group of near-natives: i.e., only in those who have started to acquire the language in question after puberty. A further confirmation of this result is given in the following section. ${ }^{25}$

\section{Extension}

In order to be sure that the results were not a by-product of a 'stylistic choice' made by these specific speakers, we compared L2ers productions in Italian with their productions in Greek. If the difference is maintained, it cannot be due to a personal stylistic choice of those speakers, otherwise we should find it also in their Greek productions. As we have shown in the section "The Near-Nativeness Level of the Subjects," Greek is these subjects' L1, and, despite their residence in Italy, they have preserved a native level of proficiency in this language (mean value 9.73,

\footnotetext{
${ }^{24}$ Given the differences between Greek and Italian outlined in footnotes 1 and 18 , we could expect cross-linguistic influence from Greek to Italian with respect to post-verbal subjects and the use of demonstratives for our L2ers.

This is however not the case: subjects in post-verbal position are $15 \%$ in the L2ers Reference Total (even less than in the Italian natives Reference Total) while demonstratives amount to only $10.8 \%$ of overt pronominal devices $(8.33 \%$ in the Italian natives Reference Total).

${ }^{25}$ These results are also strengthened, as we shall see, by the findings in Study 3 , where the productions of another group of bilinguals from birth (Bilinguals living in Italy) are analyzed. These bilinguals too, do not over-use overt pronouns in either of their languages.
} 


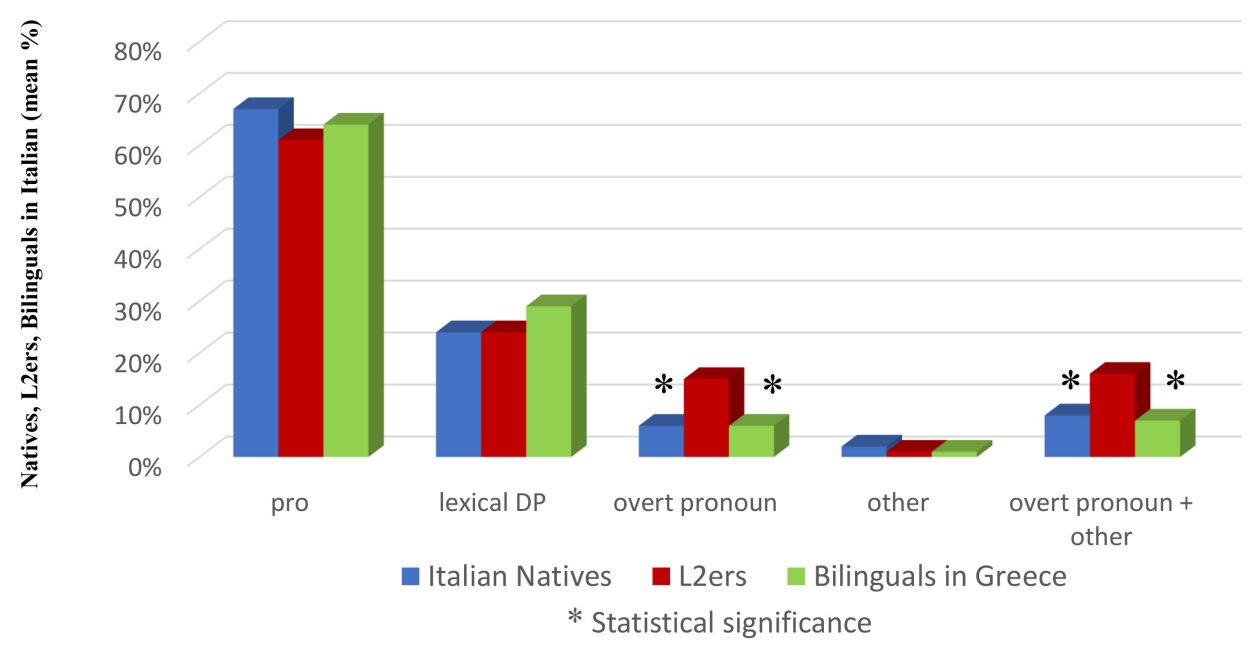

FIGURE 2 | Subject anaphoric devices in Italian: Natives, L2ers and Bilinguals.

range 9.56-9.92). With the same procedure described for Study 1, we collected the materials and derived the Reference Total, consisting of 362 sentences (Supplementary Table 5).

Again, pro is the preferred anaphoric device (65.46\%) followed by lexical DPs (27.34\%), overt pronouns (4.69\%) and 'other' (2.48\%).

When we compared the L2ers productions in Greek with their productions in Italian, we found that there are no significant differences with regard to the implementation of pro $\left(\chi^{2}=1.4176\right.$, n.s. $)$, lexical DPs $\left(\chi^{2}=1.1405\right.$, n.s. $)$ and 'other' $\left(\chi^{2}=0.7466\right.$ with Yates correction, n.s.). There is, however, a significant difference for overt pronouns: these are attested to a significantly higher extent in Italian than in Greek $\left(\chi^{2}=16.8345\right.$ with Yates correction, significant at $p<0.05 ; 0.01 ; 0.005)$. This significant difference is maintained when overt pronouns and 'other' are collapsed $\left(\chi^{2}=10.4534\right.$ with Yates correction, significant at $p<0.05 ; 0.01 ; 0.005)$. This is shown in Figure 3.

As a final point, we compared the Greek productions of the L2ers with the Greek productions of the Greek native speakers of Study 1. No significant differences are attested: pro $\left(\chi^{2}=1.4095\right.$, n.s.), lexical DP $\left(\chi^{2}=1.9132\right.$, n.s. $)$, 'other' $\left(\chi^{2}=0.6661\right.$ with Yates correction, n.s.), overt pronoun $\left(\chi^{2}=0.2495\right.$ with Yates correction, n.s.), overt pronouns and 'other' $\left(\chi^{2}=0.0010\right.$ with Yates correction, n.s.). L2ers over-use overt pronouns in their L2 only, while in their L1 their productions do not differ from those of other native speakers. This is shown in Figure 4.

\section{Interim Conclusion}

In the Introduction, we have briefly reviewed a number of studies that highlighted the role of cross-linguistic influence in determining over-use and over-acceptance of overt subject pronouns in co-reference with a topical antecedent in adult attrited speakers (Tsimpli et al., 2004), adult late acquirers (Sorace and Filiaci, 2006; Belletti et al., 2007) simultaneous bilingual children of a null and a non-null subject language (Serratrice et al., 2004; Sorace et al., 2009, a.o.). As these studies reveal, cross-linguistic influence seems to spread over different populations of bilingual speakers, although in bilingual children developmental factors can be assumed to co-occur in determining its effects, as the results in Sorace et al. (2009) show. Particularly revealing in this respect are the differences between younger and older bilingual children (with the former choosing more overt pronouns), and those concerning monolingual children and monolingual adults (again, with the former choosing more overt pronouns). This fact, together with the observed directionality of cross-linguistic influence (from the non-null subject language to the null-subject language, but not the reverse) suggests that overt pronouns are somehow simpler than null ones. The results of Sorace et al. (2009) together with those of Filiaci et al. (2013) suggest on one side that not all null-subject languages are alike with respect to the division of labor between null and overt subject pronouns, and that cross-linguistic influence may occur also in bilinguals of two null-subject languages (as highlighted by Bini's (1993) data as well).

Greek and Italian, as Study 1 reveals, are two null subject languages for which no significant quantitative differences are observed in the use of null subject pronouns, overt subject pronouns and subject lexical DPs, so that the results of Study 2 are not an effect of cross-linguistic influence. Here, we can see what cross-linguistic influence seems to obscure, i.e., a difference among different populations of near-natives, which singles out L2ers from bilinguals from birth. Another fact that Study 2 reveals is that, whatever the reason, on which we will not speculate in this work, overt pronouns appear simpler not only for children (as revealed by some of the studies quoted above) but also for adults, when age of onset of exposure to the language in question is rather late. ${ }^{26}$

${ }^{26} \mathrm{~A}$ brief examination of the contexts in which overt pronouns occurred reveals that while native speakers and bilinguals use them in topic shift contexts, in L2ers' productions this is often not the case, especially when more than one Discourse Referent is active at some specific points of the narration. Overt pronouns were however very few in our corpora, and the issue needs to be studied more in depth and with a wider range of data. We therefore leave the issue for future research. 


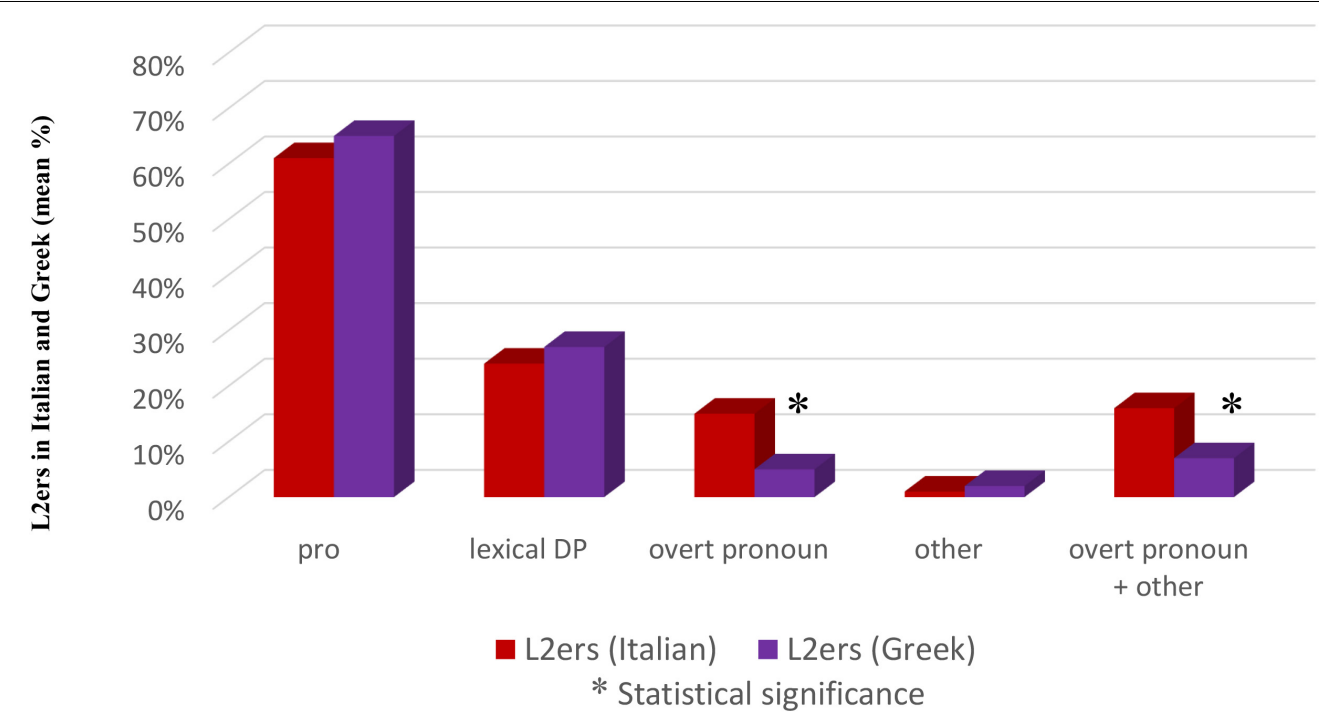

FIGURE 3 | Subject anaphoric devices in L2ers: Italian and Greek.

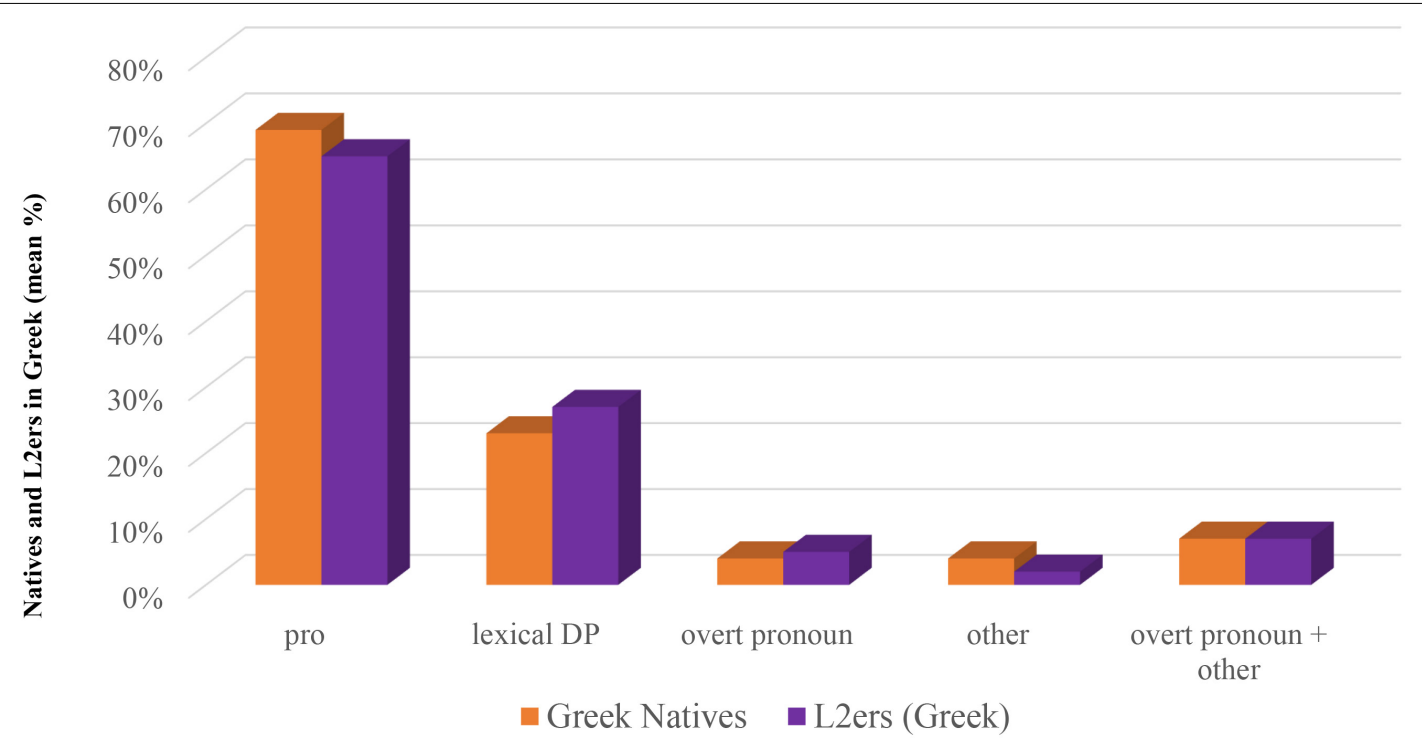

FIGURE 4 | Subject anaphoric devices in Greek: Natives and L2ers.

Absence of cross-linguistic influence has proved thus to offer a fruitful opportunity to study the role of other factors (e.g., age of onset of exposure): with this in mind, we move to Study 3.

\section{STUDY 3: THE ROLE OF DOMINANCE: COMPARING TWO GROUPS OF BILINGUALS}

The results of Study 2 suggest that age of onset of exposure to Italian is a relevant factor in determining the over-use of overt pronouns in near-natives of Italian in the absence of effects related to cross-linguistic influence. Note that the two groups were comparable, despite smaller, non-significant differences, as to the level of proficiency: they were both near-natives, and our aim is to compare natives and near-natives. ${ }^{27}$

\footnotetext{
${ }^{27}$ L2ers had a mean value of 8.88/10 in Italian and of 9.73/10 in Greek. Bilinguals in Greece had a mean value of 8.98/10 in Italian and of 9.34/10 in Greek. These differences (either within-group or between-group) are non-significant: L2ers Italian vs. Greek: $\chi^{2}=0.0174$ with Yates correction, n.s.; Bilinguals in Greece: Greek vs. Italian $\chi^{2}=0,2662$ with Yates correction, n.s.; L2ers vs. Bilinguals in Greece, Italian: $\chi^{2}=0.4239$, with Yates correction, n.s.; L2ers vs. Bilinguals in Greece, Greek; $\chi^{2}=0.4196$ with Yates correction, n.s. The data concerning Bilinguals in Greece raise an interesting issue that we leave for future research, since Bilinguals in Greece appear to be near-natives in both Italian and Greek, i.e., they appear as native speakers of none of their two languages.
} 
Level of proficiency, however, is not the only factor characterizing dominance, and if we want to study the role of dominance in near-natives, other factors have to be taken into consideration. $^{28}$

In order to verify the role of dominance, we decided to compare two different groups of bilinguals: the bilinguals of Study 2, who were living in Greece (Bilinguals in Greece) and a group of bilinguals living in Italy (Bilinguals in Italy). Besides small, non-significant, differences concerning proficiency, the two groups differ in the dimension that concerns the language of the environment (or 'predominant' language, see Silva-Corvalán and Treffers-Daller, 2016:3). ${ }^{29}$ Another relevant difference between the two groups concerns use: while Bilinguals in Greece use both Greek and Italian in everyday life, Bilinguals in Italy only use Italian in everyday life, reserving Greek basically for contacts with their family in Greece.

We first compared the Greek of these two groups, and then their Italian. Finally, an interesting comparison is a within-group comparison: the Greek vs. Italian of Bilinguals in Italy as well as the Greek vs. Italian of Bilinguals in Greece.

\section{Subjects}

20 subjects participated in Study 3: the group of 10 Bilinguals living in Greece who participated in Study 2 (Bilinguals in Greece), and a group of 10 bilinguals living in Italy (henceforth Bilinguals in Italy). Bilinguals in Greece have already been described in Study 2. Bilinguals in Italy (4 male; 6 female) had a mean age of 22 (range 19-30). They had all been exposed to both languages since birth, with one parent native speaker of Greek and one parent native speaker of Italian. They grew up mostly in Greece (where they had all attended the Italian State School of Athens) and then they moved to Italy. Their residence in Italy was 6 years on average at the time of testing. As for education, 7 had a high school degree (and were attending university in Italy) and 3 had a university degree (taken in Italy). They were tested in Italy.

\section{Materials and Methods Ethical Considerations}

The same ethical considerations holding for Study 1 (see section "Ethical Considerations") and Study 2 (see section "Ethical Considerations") hold here as well.

\footnotetext{
${ }^{28}$ See a.o Birdsong (2014), Montrul (2016), Silva-Corvalán and Treffers-Daller (2016), Treffers-Daller and Korybski (2016) and the references quoted there.

${ }^{29}$ Bilinguals in Italy had a mean value in Italian of 9.03 (range 8.69-9.38) and of 8.79 in Greek (range 8.08-9.24). As we noticed for the Bilinguals in Greece, Bilinguals in Italy appear to be native speakers of neither of their languages, too. Another fact worth noting is that their residence in Italy seems to have had a greater effect on their Greek, when compared to L2ers, which still maintain their native level in Greek notwithstanding the years spent in Italy: attrition seems to have a more pervasive effect in bilinguals than in L2ers. The nearnativeness values in each language of this group of experimental subjects is also reported in Supplementary Table 9. As for within-group and between-group statistical significance, we observed the following: Bilinguals in Italy: Greek vs. Italian $\chi^{2}=0,2974$ with Yates correction, n.s.; Bilinguals in Greece vs. Bilinguals in Italy: Greek $\chi^{2}=0,1195$ with Yates correction, n.s.; Italian $\chi^{2}=0,5036$ with Yates correction, n.s.
}

\section{Procedure}

The procedure employed to collect the data is the same described for Study 1 and Study 2, the only difference being that Bilinguals in Italy first used Greek and then Italian to tell the story. The procedure to analyze data (sentence typing, derivation of the Reference Total, determination of the subjects' near-nativeness value) is the same described for Study 1 and Study 2, as well.

\section{Results ${ }^{30}$}

The Reference Total concerning the Greek of Bilinguals in Italy consists of 251 sentences, while for their Italian of 234 sentences. The Reference Total of the Greek of Bilinguals in Greece consists of 267 sentences, while that of their Italian of 241 sentences as described in Study 2.

As mentioned, we will first perform a between-group comparison, initially comparing the Greek of the two groups, then their Italian. We will then proceed to a within-group comparison, first on Bilinguals in Italy, then on Bilinguals in Greece.

\section{Bilinguals in Italy vs. Bilinguals in Greece Bilinguals in Italy vs. Bilinguals in Greece: Greek}

In both groups pro is the anaphoric device employed most (63.34\% in Bilinguals in Italy; $76.02 \%$ in Bilinguals in Greece), followed by lexical DPs $(27.88 \%$ Bilinguals in Italy; $19.10 \%$ Bilinguals in Greece), overt pronouns (4.38\% Bilinguals in Italy; $2.24 \%$ Bilinguals in Greece) and 'other' ( $4.38 \%$ Bilinguals in Italy; $2.62 \%$ Bilinguals in Greece). When we compare the percentage rates, we do not find any significant difference concerning overt pronouns $\left(\chi^{2}=1.2466\right.$ with Yates correction, n.s.) or 'other' $\left(\chi^{2}=0.7285 \text { with Yates correction, n.s. }\right)^{31}$ The employment of lexical DPs instead differs significantly $\left(\chi^{2}=5.5802\right.$, significant at $p<0.05)$, as well as use of pro, where the difference is highly significant $\left(\chi^{2}=9.8889\right.$, significant at $\left.p<0.05 ; 0.01 ; 0.005\right)$. Bilinguals in Italy use significantly less pro and significantly more lexical DPs when compared to Bilinguals in Greece. Results are shown in Figure 5A.

\section{Bilinguals in Italy vs. Bilinguals in Greece: Italian}

In Italian pro is the mostly employed anaphoric device in both groups, too $(64.52 \%$ Bilinguals in Italy; $63.90 \%$ Bilinguals in Greece), followed by lexical DPs (24.35\% Bilinguals in Italy; $29.46 \%$ Bilinguals in Greece), overt pronouns (6.83\% Bilinguals in Italy; $5.80 \%$ Bilinguals in Greece) and 'other' (4.27\% Bilinguals in Italy; $0.82 \%$ Bilinguals in Greece). When we turn to the comparisons, we do not find any significant difference as far as overt pronouns are concerned $\left(\chi^{2}=0.0740\right.$ with Yates correction, n.s.), but we find a significant difference with respect to 'other'

\footnotetext{
${ }^{30}$ The Reference Total concerning the Greek of Bilinguals in Italy is reported in Supplementary Table 6, while the Reference Total concerning the Italian of Bilinguals in Italy is reported in Supplementary Table 7. Supplementary Table 8 reports the Reference Total concerning the Greek of Bilinguals in Greece, while the Reference Total concerning their Italian is shown in Supplementary Table 3. The tables show the Reference Total of the sentences produced, together with the clausal type and the occurrences and percentages of the kind of referring expression employed.

${ }^{31}$ When pronouns and other are collapsed we do not reach significance either, as expected $\left(\chi^{2}=2.5295\right.$ with Yates correction, n.s.).
} 

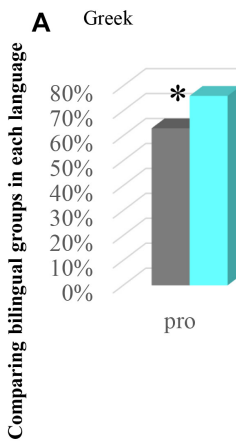
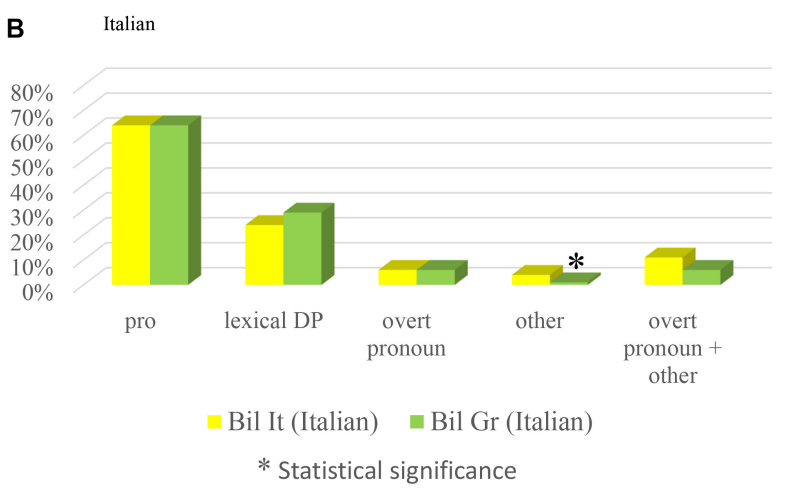

FIGURE 5 | Comparing bilingual groups in each language.

$\left(\chi^{2}=4.4045\right.$ with Yates correction, significant at $\left.p<0.05\right)$. The difference doesn't reach significance when overt pronouns and 'other' are collapsed ( $\chi^{2}=2.4172$ with Yates correction, n.s.). We do not find any significant difference with respect to pro $\left(\chi^{2}=0.0205\right.$, n.s. $)$ or lexical DPs $\left(\chi^{2}=1.5696\right.$, n.s. $)$. Results are shown in Figure 5B.

\section{Interim discussion}

As Figure 5 shows, the Italian of these two groups of speakers is quite uniform, with the exception of a significant difference concerning 'other', more employed by Bilinguals in Italy.

There are indeed some interesting differences concerning the Greek of these two groups of speakers, in that, compared to Bilinguals in Greece, Bilinguals in Italy use significantly less pro and significantly more lexical DPs. This could prima facie suggest that, although dominance does not affect the productions of overt pronouns, it has some effects in the choice of referring expressions, in that pro is less used by those speakers who don't use this language in everyday life. This conclusion, however, needs further confirmation, since it could be rather the group which uses both languages in everyday life, i.e., Bilinguals in Greece, the one who manifests a peculiarity.

\section{Within-Group Comparison \\ Bilinguals in Italy: Greek vs. Italian}

The within-group comparison concerning the Greek and the Italian of Bilinguals in Italy shows that pro is the most employed anaphoric device in both languages (63.34\% in Greek; 64.52\% in Italian) followed by lexical DPs (27.88\% in Greek; $24.35 \%$ in Italian), overt pronouns (4.38\% in Greek; $6.83 \%$ in Italian) and other (4.38\% in Greek; $4.27 \%$ in Italian). The comparison reveals no significant differences with respect to pro $\left(\chi^{2}=0.0735\right.$, n.s.), lexical DP ( $\chi^{2}=0.7805$, n.s. $)$, overt pronouns ( $\chi^{2}=0.9608$, n.s.), 'other' $\left(\chi^{2}=0.0270\right.$, n.s. $)$, nor when collapsing overt pronouns and 'other' $\left(\chi^{2}=0.5076\right.$, n.s.). Results are shown in Figure 6A.

\section{Bilinguals in Greece: Greek vs. Italian}

The within-group comparison concerning the Greek and the Italian of Bilinguals in Greece shows that pro is the most employed anaphoric device in both languages (76.02\% in Greek; $63.90 \%$ in Italian), followed by lexical DPs (19.10\% in Greek; $29.46 \%$ in Italian), overt pronouns $(2.24 \%$ in Greek; $5.80 \%$ in Italian), and 'other' (2.62\% in Greek; $0.82 \%$ in Italian). The comparison reveals, however, some significant differences: this is so in the case of pro $\left(\chi^{2}=8.9215\right.$, significant at $p<0.05$; $0.01 ; 0.005)$ and of lexical DPs $\left(\chi^{2}=7.4494\right.$, significant at $p<0.05 ; 0.01)$. The use of overt pronouns instead does not reveal significant differences in the two languages $\left(\chi^{2}=3.3596\right.$ with Yates correction, n.s.), as well as 'other' ( $\chi^{2}=1.4207$ with Yates correction, n.s.) or, as expected, collapsing overt pronouns and 'other' ( $\chi^{2}=0.4451$ with Yates correction, n.s.). Results are shown in Figure 6B.

\section{Interim discussion}

The within-group comparison, shown in Figure 6, reveals an interesting fact: while Bilinguals in Italy make the same choice of referential expressions in the language they daily use (Italian) and in the one they seldom use (Greek), Bilinguals in Greece instead differ significantly: they use significantly more pro in Greek than in Italian, conversely using more lexical DPs in Italian than in Greek. In contrast, overt pronouns are used to a comparable extent in the two languages.

As we have seen in Study 1, however, in Italian we did not find significant differences between Bilinguals in Greece and Native speakers of Italian, neither for overt pronouns, nor pro, nor lexical DPs. There are therefore strong reasons to believe that the difference concerns rather their predominant language, i.e., Greek.

\section{Extensions and Final Discussion}

At this point, in order to have a clearer picture, we will compare the Greek of all groups discussed in this paper (Natives, Bilinguals in Greece, L2ers, Bilinguals in Italy) as well as their Italian. Let's start with Greek. As for pro, Bilinguals in Greece significantly differ from Bilinguals in Italy (as shown in the section 'Bilinguals in Italy vs. Bilinguals in Greece: Greek') and from L2ers $\left(\chi^{2}=8.1529\right.$, significant at $p<0.05$; 0.01) though not from Natives $\left(\chi^{2}=3.6719\right.$, n.s.). As for lexical DPs, Bilinguals in Greece again, besides the significant difference with respect to Bilinguals in Italy singled out in the section 'Bilinguals in Italy 


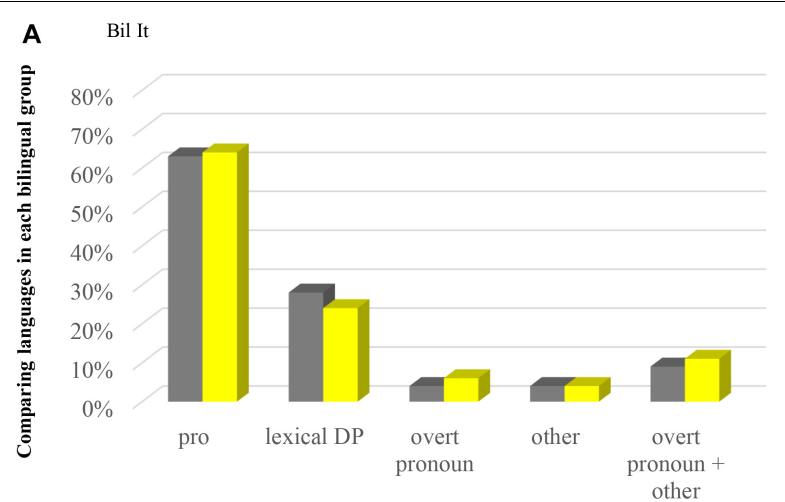

- Bil It (Greek) $\quad$ Bil It (Italian)
B Bil Gr

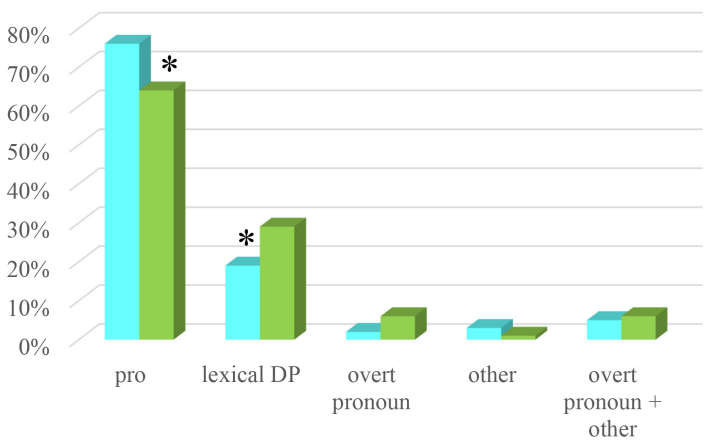

घil Gr (Greek) $\quad$ घil Gr (Italian)

* Statistical significance

FIGURE 6 | Comparing languages in each bilingual group.

vs. Bilinguals in Greece: Greek') show a significant difference also with respect to L2ers $\left(\chi^{2}=5.7548\right.$, significant at $\left.p<0.5\right)$, though not with respect to Natives $\left(\chi^{2}=1.6077\right.$, n.s. $)$. We didn't find any other significant difference in this comparison: for pro, Bilinguals in Italy vs. Natives $\left(\chi^{2}=2.6737\right.$, n.s.), Bilinguals in Italy vs. L2ers $\left(\chi^{2}=0.2921\right.$, n.s. $)$; for lexical DPs, Bilinguals in Italy vs. Natives $\left(\chi^{2}=1.9631\right.$, n.s.), Bilinguals in Italy vs. L2ers $\left(\chi^{2}=0.0217\right.$, n.s. $)$; for overt pronouns, Bilinguals in Italy vs. Natives $\left(\chi^{2}=0.0458\right.$ with Yates correction, n.s.), Bilinguals in Italy vs. L2ers ( $\chi^{2}=0.0002$ with Yates correction, n.s.), Bilinguals in Greece vs. Natives ( $\chi^{2}=0.7838$ with Yates correction, n.s.), Bilinguals in Greece vs. L2ers ( $\chi^{2}=1.9670$ with Yates correction, n.s.); for 'other', Bilinguals in Italy vs. Natives $\left(\chi^{2}=0.0458\right.$ with Yates correction, n.s.), Bilinguals in Italy vs. L2ers $\left(\chi^{2}=1.1414\right.$ with Yates correction, n.s.), Bilinguals in Greece vs. Natives $\left(\chi^{2}=0.3559\right.$ with Yates correction, n.s.), Bilinguals in Greece vs.
L2ers $\left(\chi^{2}=0.0223\right.$ with Yates correction, n.s.); for overt pronoun + 'other,' Bilinguals in Italy vs. Natives $\left(\chi^{2}=0.2065\right.$ with Yates correction, n.s.), Bilinguals in Italy vs. L2ers $\left(\chi^{2}=0.3185\right.$ with Yates correction, n.s.), Bilinguals in Greece vs. Natives $\left(\chi^{2}=1.4884\right.$ with Yates correction, n.s.), Bilinguals in Greece vs. L2ers $\left(\chi^{2}=1.0442\right.$ with Yates correction, n.s.). Results are shown in Figure 7.

As far as Italian is concerned results show that L2ers significantly differ in the use of overt pronouns not only with respect to Natives and Bilinguals in Greece (as shown in Study 2) but also with respect to Bilinguals in Italy $\left(\chi^{2}=6.6599\right.$ with Yates correction, significant at $p<0.05 ; 0.01)$. This significance with respect to Bilinguals in Italy is lost when overt pronouns are collapsed with 'other' $\left(\chi^{2}=1.8134\right.$ with Yates correction, n.s.). As we have seen in the section "Bilinguals in Italy vs. Bilinguals in Greece: Italian," Bilinguals in Italy use significantly

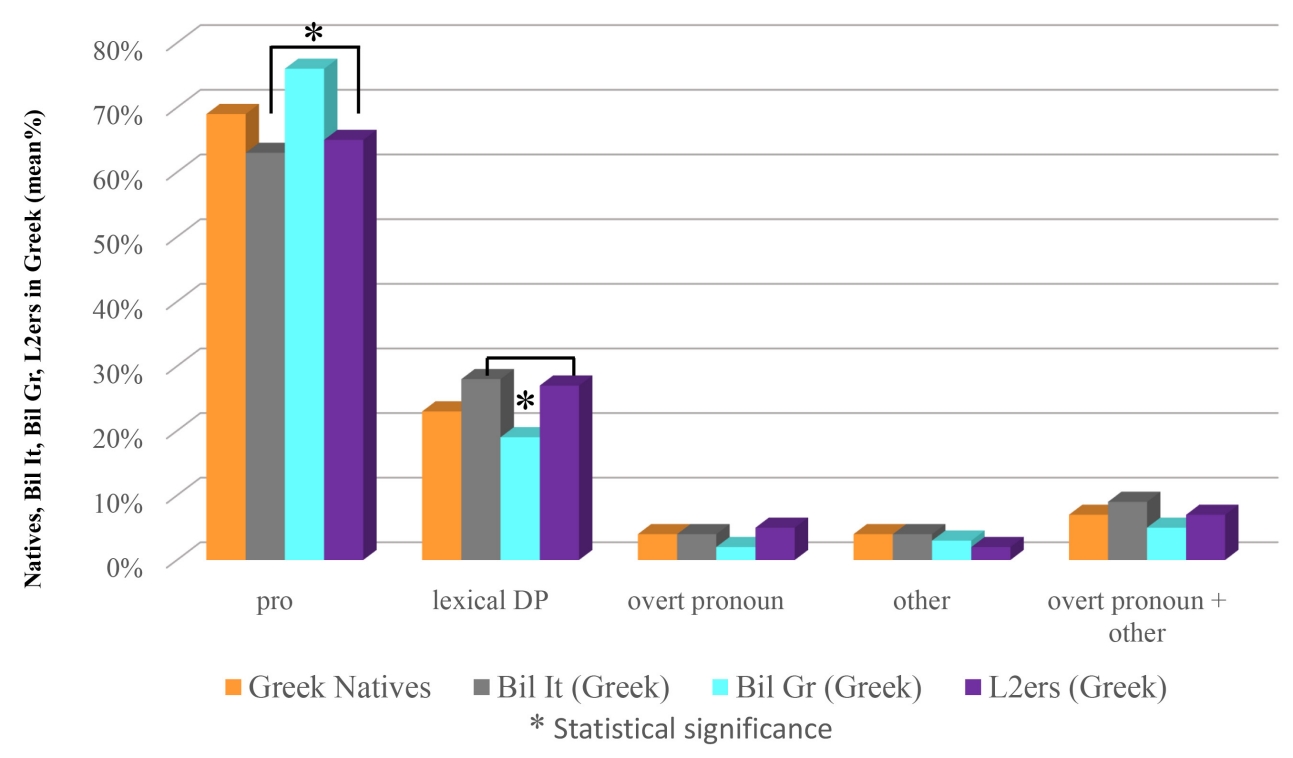

FIGURE 7 | Subject anaphoric devices in Greek: all groups. 
more 'other' than Bilinguals in Greece. It is not so when we compare Bilinguals in Italy to L2ers $\left(\chi^{2}=3.4052\right.$ with Yates correction, n.s.) or to Natives $\left(\chi^{2}=1.7991\right.$ with Yates correction, n.s.). We didn't find any other significant difference in this comparison: for pro, Bilinguals in Italy vs. Natives $\left(\chi^{2}=0.4588\right.$, n.s.), Bilinguals in Italy vs. L2ers $\left(\chi^{2}=0.7310\right.$, n.s. $)$; for lexical DPs, Bilinguals in Italy vs. Natives $\left(\chi^{2}=0.0004\right.$, n.s.), Bilinguals in Italy vs. L2ers $\left(\chi^{2}=0.0461\right.$, n.s.); for overt pronoun, Bilinguals in Italy vs. Natives $\left(\chi^{2}=0.0208\right.$ with Yates correction, n.s.); for overt pronoun + 'other', Bilinguals in Italy vs. Natives $\left(\chi^{2}=1.0759\right.$ with Yates correction, n.s.). Results are shown in Figure 8.

The comparisons shown in Figure 7, concerning Greek, single out that Bilinguals in Greece use significantly more pros, and significantly less lexical DPs, when compared to both Bilinguals in Italy and L2ers, though not when compared to Natives. The fact that the difference is not restricted to a single group, together with the data described in the section "Within-Group Comparison" allows us to argue that it is precisely this group of speakers that is doing something peculiar, and that is doing so in the predominant language. As we can see in Figure 1 (which pertains to Study 1) native speakers of Greek use more pros and less lexical DPs than Italian natives. This difference, as we noted, is far from significant, however: it has led us to assume that Italian and Greek are very similar with respect to the choice of anaphoric devices. What these bilinguals do, we argue, is amplifying this little difference, modifying their choices in the predominant language. Similar facts have been noted in situations of language contact (see e.g., Scala, 2018 and the references quoted there), where two languages appear more divergent when they are in contact than when they are spoken in non-contact areas, and have been considered therefore a driving factor of language change. As we said in the section "Materials and Methods," Bilinguals in Greece use Italian (as well as Greek) on a regular basis (differently from Bilinguals in Italy, as well as from L2ers, who use Greek basically just for contacts with their family in Greece). Bilinguals in Greece either attend the Italian State School of Athens or use Italian for their work, and they live in Greece. They are the only group, among our experimental subjects, who employs the two languages in everyday life. Amplifying the differences in the two languages helps these bilingual speakers keeping the two languages separate.

Interestingly, the modification does not involve overt pronouns, but lexical DPs as well as null pronouns. This suggests that overt pronouns are a really marked option, questioning accessibility marking scales such as those in Ariel (1990, 2001) which place overt pronouns near to null ones.

The comparisons shown in Figure 8, concerning Italian, confirm the results of Study 2 (over-use of subject overt pronouns by L2ers) and extend their validity with respect to Bilinguals in Italy (though significance is lost when overt pronouns are collapsed with 'other'). They also highlight that the significant over-use of 'other' by Bilinguals in Italy with respect to Bilinguals in Greece is restricted to this case, hence no reliable conclusions can be drawn in this respect.

\section{CONCLUSION}

In Study 1, we have presented evidence that native speakers of Greek and of Italian do not differ significantly in the choice of subject anaphoric devices, at least as far as production is concerned: pro is overwhelmingly the most attested device, followed by lexical DPs, while overt pronouns are very few in both groups. Italian-Greek is therefore a suitable language combination if we want to study bilinguals' choices in this respect, since effects related to cross-linguistic influence are absent. This does not mean, of course, that we want to deny, in general, the effects of cross-linguistic influence on the choice of anaphoric devices in bilinguals, since this is clearly demonstrated by several

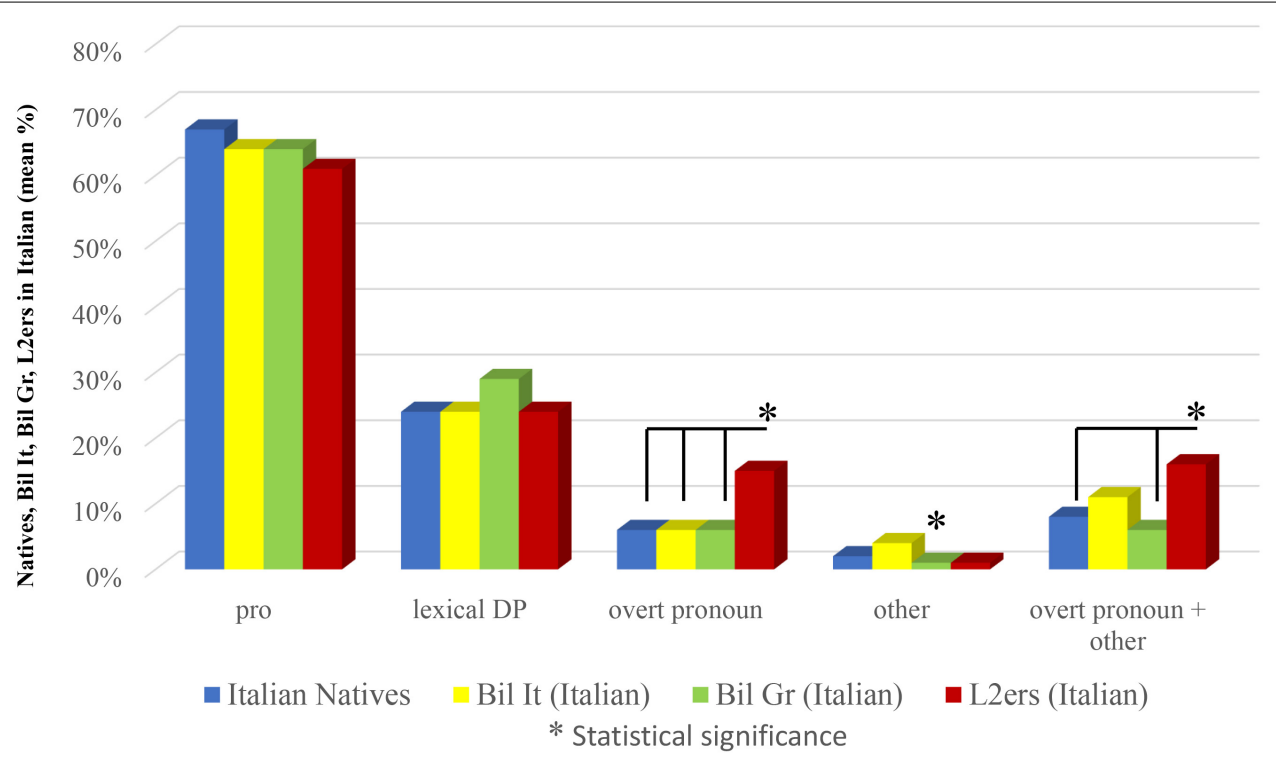

FIGURE 8 | Subject anaphoric devices in Italian: all groups. 
studies. Absence of cross-linguistic influence, however, allows the discovery of other factors playing a role in the issue at stake.

In Study 2, we have compared the productions in Italian of a group of native speakers and two groups of near-natives: a group of bilinguals from birth (Bilinguals in Greece) and a group with post-puberty age of onset of exposure to Italian (L2ers). We have given evidence that over-use of overt subject pronouns in near-natives of Italian takes place when effects related to cross-linguistic influence are absent, singling out that this holds for a specific population of near-natives: those with age of initial exposure to the language in question after puberty. Tsimpli (2014) argues that phenomena which are acquired late (such as pragmatically conditioned aspects of pronominal use) do not cause pronounced differences among bilinguals differing for age of initial exposure. Our study suggests that this claim is valid for pre-puberty but not for post-puberty age of onset of exposure.

As a reviewer wisely observes, the two groups of near-natives in Study 2 do not differ only with respect to age of onset of exposure to Italian, but also with respect to language of the environment: while L2ers live in Italy, Bilinguals in Greece live in Greece. The comparison between L2ers and another group of bilinguals from birth (the Bilinguals in Italy of Study 3 ) with the same language of the environment as the L2ers (Italian) confirms, however, the very same result: L2ers resort to overt pronouns significantly more than native speakers and bilinguals from birth, as shown in Figure 8.

The language of the environment (or 'majority language,' or 'predominant language'), one of the variables characterizing dominance, does not seem to have an effect on the choice of overt pronouns, as confirmed by Study 3 .

This variable, however, combined with regular use of the two languages, has indeed an effect in the choice of anaphoric devices such as pro and lexical DPs, though in a direction we did not expect: it is in the predominant language, rather than in the non-predominant one, that differences between natives and bilinguals have been observed. We have interpreted these differences as stemming from the bilinguals' need to keep the two languages they daily use as distant as possible. Interestingly, these differences do not involve overt pronouns, but concern a wider use of null pronouns which charges lexical DPs. This suggests that overt pronouns are a marked option, questioning accessibility marking scales such as those in Ariel (1990, 2001) which place overt pronouns near to null ones. As a reviewer suggests, the significantly higher use of pro in Greek by Bilinguals in Greece might also reflect an underlying property of Greek pro, which, according to some authors appears to be compatible with salient/subject antecedent but also with non-salient/ object antecedent (Dimitriadis, 1996; Torregrossa et al., 2015). At a first analysis, our data are not very clear in this respect, and we have to leave this issue for future research.

\section{REFERENCES}

Alexiadou, A., and Anagnostopoulou, E. (2002). "Raising without infinitives and the role of agreement," in Dimensions of Movement, eds A. Alexiadou, E. Anagnostopoulou, S. Barbiers, and H. M. Gärtner (Amsterdam: John Benjamins Publishing Company), 17-30.
A final note concerns the small-scale nature of our corpora, which has proven particularly limiting in the case of overt pronouns (which are seldom produced by our subjects) preventing a serious qualitative analysis of the contexts in which they occur in natives, bilinguals and L2ers. Another issue which we leave for future research is thus an inquiry with a wider range of data, collected with the help of different tasks, as a reviewer suggests.

\section{AUTHOR CONTRIBUTIONS}

EDD developed the rationale of the study, the study concept and design, and wrote the manuscript. IB contributed in data collection. EDD and IB contributed in data analysis and its interpretation. Both authors critically read the manuscript providing comments that helped to improve its final version, and approved the final version for submission.

\section{FUNDING}

This research was supported by the Università per Stranieri di Perugia, D.R. 196/2018 and Progetto di Ricerca di Ateneo Di Domenico 2017 and Di Domenico 2018.

\section{ACKNOWLEDGMENTS}

Parts of this work have been presented at Eurosla 27 (University of Reading, August 29-September 2, 2017), at GALA 13 (Universitat de les Illes Balears September 7-9, 2017), at the Linguistics Colloquia held at the University of Perugia (November 21, 2017), at the 44th Incontro di Grammatica Generativa (Università di Roma III, March 1-3, 2018) and at the workshop 'Overt subject pronouns in null-subject languages' (Università per Stranieri di Perugia, September 13, 2018). We thank the audience at these conferences and the two Frontiers reviewers of this paper for helpful comments and suggestions. Special thanks are due to the Italian State School of Athens (in the person of Marta Zanardo, pro-Rector of the school at the time of the data collection), and to all our experimental subjects. Finally, we would like to thank Antonello Belli, Carla Contemori, Francesca Filiaci, Jihye Kang, and Simona Matteini. All errors and shortcomings are of course our own.

\section{SUPPLEMENTARY MATERIAL}

The Supplementary Material for this article can be found online at: https://www.frontiersin.org/articles/10.3389/fpsyg. 2018.02729/full\#supplementary-material

\footnotetext{
Ariel, M. (1990). Accessing Noun Phrase Antecedents. London: Routledge.

Ariel, M. (2001). "Accessibility theory: an overview," in Text Representation: Linguistic and Psycholinguistic aspects, eds T. Sanders, J. Schilperoord, and W. Spooren (Amsterdam: John Benjamins Publishing Company), 29-87. doi: 10.1075 /hcp.8.04ari
} 
Belletti, A. (2001). "Inversion' as focalization," in Subject Inversion and the Theory of Universal Grammar, eds A. Hulk and J. Y. Pollock (Oxford: Oxford University Press), 60-90.

Belletti, A. (2004). "Aspects of the low IP area," in The Cartography of Syntactic Structures vol. II: The Structure of CP and IP, ed. L. Rizzi (Oxford: Oxford University Press), 16-51.

Belletti, A., Bennati, E., and Sorace, A. (2007). Theoretical and developmental issues in the syntax of subjects: evidence from near-native Italian. Nat. Lang. Linguist. Theory 25, 657-689. doi: 10.1007/s11049-007-9026-9

Bini, M. (1993). "La adquisicíon del italiano: mas allá de las propiedades sintácticas del parámetro pro-drop," in La Linguistica y el Analisis de los Sistemas no Natives, ed. L. Liceras (Ottawa: Doverhouse), 126-139.

Birdsong, D. (2014). Dominance and age in bilingualism. Appl. Linguist. 35, 374-392. doi: 10.1093/applin/amu031

Calabrese, A. (1986). "Pronomina," in Papers in Theoretical Linguistics, eds N. Fukui, T. R. Rapoport, and E. Sagey (Cambridge, MA: MITWPL), 1-46.

Carminati, M. N. (2002). The Processing of Italian Subject Pronouns. Doctoral Dissertation, University of Massachusetts, Amherst, MA.

Chafe, W. (ed.) (1980). The Pear Stories: Cognitive, Cultural, and Linguistic Aspects of Narrative Production. Norwood, NJ: Ablex.

Chiou, M. (2013). Performing anaphora in modern greek: a neo-gricean pragmatic analysis. Res. Lang. 11, 335-358. doi: 10.2478/v10015-012-0029-1

Chomsky, N. (1981). Lectures on Government and Binding. Dordrecht: Foris.

Contemori, C., Dal Pozzo, L., and Matteini, S. (2015). "Resolving pronominal anaphora in real-time: a comparison between Italian native and near-native speakers," in Structures, Strategies and Beyond. Studies in Honour of Adriana Belletti, eds E. Di Domenico, C. Hamann, and S. Matteini (Philadelfia, PA: John Benjamins Publishing Company), 257-276. doi: 10.1075/la.223.12con

Dal Pozzo, L., and Matteini, S. (2015). "(In)definiteness and near-nativeness: article choice at interfaces," in Language Acquisition and Development: Proceedings of GALA 2013, eds C. Hamann and E. Ruigendijk (Newcastle upon Tyne: Cambridge Scholars Publishing), 61-82.

Dimitriadis, A. (1996). "When pro-drop languages don't: overt pronominal subjects and pragmatic inference," in Proceedings of the Chicago Linguistic Society, Vol. 32, eds L. M. Dobrin, K. Singer, and L. McNair (Chicago, IL: Chicago Linguistic Society), 33-47.

Filiaci, F., Sorace, A., and Carreiras, M. (2013). Anaphoric biases of null and overt subjects in Italian and Spanish: a cross-linguistic comparison. Lang. Cogn. Neurosci. 28, 825-843. doi: 10.1080/01690965.2013.801502

Grice, P. (1975). "Logic and conversation," in Syntax and Semantics - Speech Acts, eds P. Cole and J. L. Morgans (New York, NY: Academic Press), 41-58.

Hacohen, A., and Schaeffer, J. (2007). Subject realization in early Hebrew-English bilingual acquisition: the role of cross-linguistic influence. Bilingualism 10, 333-344. doi: 10.1017/S1366728907003100

Hulk, A., and Müller, N. (2000). Cross-linguistic influence at the interface between syntax and pragmatics. Bilingualism 3, 227-244. doi: 10.1017/ S1366728900000353

Ingria, R. (2005). Grammatical formatives in a generative lexical theory. the case of modern Greek kal. J. Greek Linguist. 6, 61-101. doi: 10.1075/jgl.6.06ing

Lambrecht, K. (1994). Information Structure and Sentence Form. Cambridge: Cambridge University Press. doi: 10.1017/CBO9780511620607

MacWhinney, B. (2000). The CHILDES Project: Tools for Analyzing Tool, 3rd Edn. Mahwah, NJ: Lawrence Erlbaum Associates.

Montrul, S. (2016). "Dominance and proficiency in early and late bilingualism," in Language Dominance in Bilinguals. Issues of Measurement and Operationalization, eds C. Silva-Corvalán and J. Treffers-Daller (Cambridge: Cambridge University Press), 15-35. doi: 10.1017/CBO978110737 5345.002

Panagiotidis, P. (2000). Demonstrative determiners and operators: the case of Greek. Lingua 110, 717-742. doi: 10.1016/S0024-3841(00)00014-0

Paradis, J., and Navarro, S. (2003). Subject realization and cross-linguistic interference in the bilingual acquisition of Spanish and English: what is the role of input? J. Child Lang. 30, 1-23. doi: 10.1017/S0305000903005609

Philippaki-Warburton, I., and Catsimali, G. (1999). "On control in modern Greek," in Studies in Greek Syntax, eds A. Alexiadou, G. Horrocks, and M. Stavrou (Dordrecht: Kluwer Academic Publishers), 153-168. doi: 10.1007/978-94-0159177-5_8

Pinto, M. (2006). "Subject pronouns in bilinguals: interference or maturation?", in The Acquisition of Syntax in Romance Languages, eds V. Torrens and L. Escobar (Amsterdam: Benjamins), 331-352. doi: 10.1075/lald.41. 16 pin

Rizzi, L. (1982). Issues in Italian Syntax. Berlin: Walter de Gruyter. doi: 10.1515/ 9783110883718

Rizzi, L. (2005). "On some properties of subjects and topics," in Proceedings of the XXX Incontro di Grammatica Generativa, eds L. Brugè, G. Giusti, N. Munaro, W. Schweikert, and G. Turano (Venezia: Cafoscarina), 203-224.

Rizzi, L. (2018). "Subjects, topics and the interpretation of pro," in From Sounds to Structures: Beyond the Veil of Maya, eds R. Petrosino, P. Cerrone, and H. van der Hulst (Berlin: De Gruyter Mouton), 510-529. doi: 10.1515/9781501506734-019 Roussou, A., and Tsimpli, I. M. (2006). On Greek VSO again! J. Linguist. 42, 317-344. doi: 10.1017/S0022226706003914

Scala, A. (2018). "I dialetti armeni tra continuità lessicale e innovazioni strutturali a modello turcico," in Mutamento Linguistico e Biodiversità. Atti del XVI Convegno Annuale Della Società Italiana di Glottologia, eds L. Costamagna, E. Di Domenico, A. Marcaccio, S. Scaglione, and B. Turchetta (Roma: Il Calamo), 189-208.

Serratrice, L., Sorace, A., and Paoli, S. (2004). Crosslinguistic influence at the syntax-pragmatics interface: subjects and objects in Italian-English bilingual and monolingual acquisition. Bilingualism 7, 183-206. doi: 10.1017/ S1366728904001610

Silva-Corvalán, C., and Treffers-Daller, J. (2016). "Digging into dominance: a closer look at language dominance in bilinguals," in Language Dominance in Bilinguals. Issues of Measurement and Operationalization, eds C. Silva-Corvalán and J. Treffers-Daller (Cambridge: Cambridge University Press), 1-14. doi: 10.1017/CBO9781107375345

Sorace, A. (2006). "Interfaces in L2 development," in Language Acquisition and Development. Proceedings of GALA 2005, eds A. Belletti, E. Bennati, C. Chesi, E. Di Domenico, and I. Ferrari (Newcastle upon Tyne: Cambridge Scholars Press), 505-521.

Sorace, A. (2011). Pinning down the concept of 'interface' in bilinguals. Linguist. Approaches Biling. 1, 1-33. doi: 10.1075/lab.1.1.01sor

Sorace, A., and Filiaci, F. (2006). Anaphora resolution in near-native speakers of Italian. Second Lang. Res. 22, 339-368. doi: 10.1191/0267658306sr271oa

Sorace, A., Serratrice, L., Filiaci, F., and Baldo, M. (2009). Discourse conditions on subject pronoun realization: testing the linguistic intuitions of older bilingual children. Lingua 119, 460-477. doi: 10.1016/j.lingua.2008.09.008

Spyropoulos, V. (2007). "Finiteness and control in Greek," in New Horizons in the Analysis of Control and Raising, eds W. D. Davies and S. Dubinsky (Dordrecht: Springer), 159-183. doi: 10.1007/978-1-4020-6176-9_7

Torregrossa, J., Bongartz, C., and Tsimpli, I. (2015). "Testing accessibility: a crosslinguistic comparison of the syntax of referring expressions," in Proceedings of the 89th Annual Meeting of the Linguistic Society of America (Portland), (Salt Lake, UT: Linguistic Society of America). doi: 10.3765/exabs.v0i0.3046

Treffers-Daller, J., and Korybski, T. (2016). "Using lexical diversity measures to operationalize language dominance in bilinguals," in Language Dominance in Bilinguals. Issues of Measurement and Operationalization, eds C. Silva-Corvalán and J. Treffers-Daller (Cambridge: Cambridge University Press), 106-133. doi: 10.1017/CBO9781107375345.006

Tsimpli, I. (2014). Early, late or very late. Timing acquisition and bilingualism. Linguist. Approaches Biling. 4, 283-313. doi: 10.1075/lab.4.3.01tsi

Tsimpli, I., Sorace, A., Heycock, C., and Filiaci, F. (2004). First language attrition and syntactic subjects: a study of Greek and Italian near native speakers of English. Int. J. Biling. 8, 257-277. doi: 10.1177/13670069040080030601

White, L., and Genesee, F. (1996). How native is near-native? The issue of ultimate attainment in adult second language acquisition. Second Lang. Res. 12, 233-265. doi: $10.1177 / 026765839601200301$

Conflict of Interest Statement: The authors declare that the research was conducted in the absence of any commercial or financial relationships that could be construed as a potential conflict of interest.

Copyright (c) 2019 Di Domenico and Baroncini. This is an open-access article distributed under the terms of the Creative Commons Attribution License (CC BY). The use, distribution or reproduction in other forums is permitted, provided the original author(s) and the copyright owner(s) are credited and that the original publication in this journal is cited, in accordance with accepted academic practice. No use, distribution or reproduction is permitted which does not comply with these terms. 